\title{
ПОТРЕБА НАСЕЛЕННЯ В ПАЛІАТИВНІЙ ДОПОМОЗІ НА ПРИКЛАДІ БЕРИСЛАВСЬКОГО ГОСПІТАЛЬНОГО ОКРУГУ
}

\author{
О. В. Іванчук, А. О. Боб \\ Бериславський медичний коледж \\ ДВНЗ «Тернопільський державний медичний університет \\ імені І. Я. Горбачевського МОЗ Украӥни"
}

Паліативна допомога набуває великого значення в системі охорони здоров’я. Під впливом зростання кількості тяжкохворих та інкурабельних осіб виникає необхідність розвитку та вдосконалення паліативної допомоги на території України. Покращення стану паліативної та хоспісної допомоги залишається пріоритетним у покращенні якості життя всього населення.

\section{THE NEED FOR POPULATION IN PALLIATIVE CARE ON AN EXAMPLE OF BERYSLAV HOSPITAL REGION}

\author{
O. V. Ivanchuk, A. O. Bob \\ Beryslav Medical College \\ I. Horbachevsky Ternopil State Medical University
}

Palliative care is gaining ground in the health system. Under the influence of an increase in the number of seriously ill and incurable persons, there is a need for the development and improvement of palliative care on the territory of Ukraine. Improving the state of palliative and hospice care remains a priority in improving the quality of life of the entire population.

Вступ. Однією з головних проблем XXI століття $\epsilon$ вдосконалення та подальший розвиток паліативної допомоги. Паліативна допомога - це відносно новий компонент у сучасній медицині, однак за останніми показниками вона набуває великого значення в системі охорони здоров'я. Потреба в паліативній допомозі населенню збільшується внаслідок високого зростання смертності через серцево-судинні хвороби, злоякісні пухлини, туберкульоз, цукровий діабет та низку інших захворювань. Основним завданням паліативної допомоги є забезпечення максимально можливої якості життя пацієнту і членам його родини шляхом вирішення фізичних, психологічних та духовних проблем, які мають місце у пацієнта [1].

Метою дослідження було вивчення потреби населення Бериславського госпітального округу в паліативній допомозі.

Основна частина. Наближення України до європейських цінностей та стандартів вимагає великих змін у кожній галузі. Не виключенням є система охо-

(c) О. В. Іванчук, А. О. Боб, 2018 рони здоров'я. Оскільки медична реформа має на меті забезпечити всім громадянам України рівний доступ до якісних медичних послуг, особливу увагу слід приділяти паліативній та хоспісній допомозі. Рівень та якість паліативної допомоги держави залежить від різних аспектів: фінансових, законодавчих та організаційних.

Оскільки кількість хворих, хвороба яких не піддається лікуванню, кожного року зростає, це потребує насамперед змін з організаційного боку. Тобто створення:

- спеціалізованих закладів-хоспісів і центрів ПХД;

- спеціалізованих відділень для паліативних пацієнтів в існуючих терапевтичних та багатопрофільних лікарнях і спеціалізованих диспансерах (онкологічного, психіатричного, фтизіатричного профілю тощо), а також центрах профілактики і боротьби зі СНІДом;

- спеціалізованих паліативних палат в онкологічних, неврологічних та інших відділеннях в існуючих лікарнях;

- спеціалізованих бригад ПХД для обслуговування хворих вдома; 
- відділень паліативної допомоги в закладах соціальної сфери - геріатричних пансіонатах та інтернатах, територіальних центрах соціального обслуговування громадян тощо [2].

За даними ГО «Українська ліга розвитку паліативної та хоспісної допомоги», станом на початок 2017 р. в Україні функціонує лише 7 хоспісів, 2 центри надання паліативної допомоги, а також понад 60 спеціалізованих паліативних відділень. Звичайно, що така кількість закладів не може повноцінно забезпечити належний рівень паліативної та хоспісної допомоги, що в результаті сотні тисяч хворих залишаються вдома зі своїми стражданнями.

Відповідно до реєстру паліативних хворих Бериславського госпітального округу, який включає: Бериславський, Великоолександрівський, Високопільський та Нововоронцовський райони, потребу в паліативній допомозі, згідно з рекомендаціями ВОО3, мають 1432 особи (рис. 1).

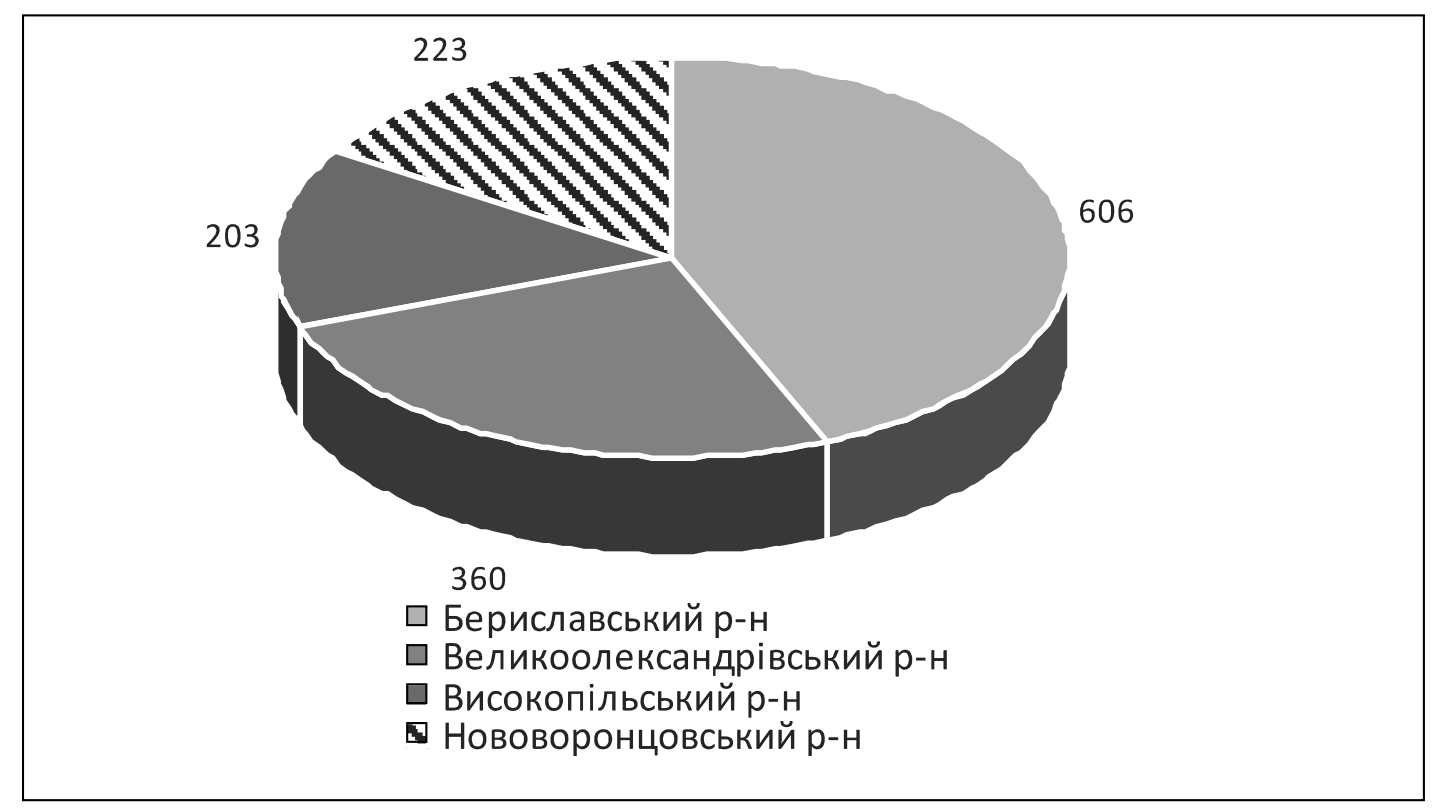

PUC. 1. Потреба в паліативній допомозі.

Фактичну потребу в паліативній допомозі, згідно з даними Центру первинної медико-санітарної допомоги, мають:

- з онкологічними захворюваннями - 88 осіб;

- іншого генезу - 493 особи.

Надання паліативної допомоги у Херсонській області надає лише обласна лікарня «Хоспіс», яка розташована у м. Херсоні. При значній потребі населення в наданні паліативної допомоги необхідні подальше створення та розвиток доступної системи закладів паліативної та хоспісної медицини в області та в державі в цілому, адже кожен пацієнт має право на отримання ефективного знеболювання і лікування, психологічну і моральну підтримку, духовний супровід та повагу. Для створення дійсно сучасного рівня допомоги невиліковним хворим не достатнє лише залучення держави.
Висновки. На сьогодні паліативна та хоспісна допомога в Україні потребує суттєвих змін. Надання всебічної допомоги населенню не можливе без встановлення належної системи паліативної допомоги, яка 6 мала на меті забезпечити всіх невиліковних хворих, які потребують належного догляду та лікування. Зростання потреби в паліативній допомозі внаслідок тяжких онкологічних та інших захворювань потребує розгалуження системи паліативних та хоспісних закладів на території України. Розвиток та вдосконалення повинні проходити комплексно: за участю громадськості та благодійних фондів. Через нестачу коштів у хоспісах не завжди вистачає необхідних речей для досконалого догляду та надання того рівня, який потребує стандарт.

Лише створивши повноцінний рівень надання паліативної та хоспісної допомоги Україна стане на крок ближче до європейських стандартів життя. 


\section{СПИСОК ЛІТЕРАТУРИ}

1. Боб А. О. Вплив медсестринського догляду на якість життя паліативних пацієнтів / А. О. Боб, Т. В. Томчук, Г. О. Лукіна // Медсестринство. - 2017. - № 1. - С. 36-40.

2. Боб А. О. Роль медичної сестри у подоланні відчуття самотності в пацієнтів хоспісу / А. О. Боб, Т. В. Томчук // Медсестринство. - 2016. - № 4. - С. 47-49.

3. Князевич В. М. Стан, проблеми і перспективи впровадження «Національної стратегії розвитку системи паліативної допомоги в Україні до 2022 року» / В. М. Князевич,
А. В. Царенко, І. В. Яковенко // Реабілітація та паліативна допомога. - 2015. - № 1 (1). - С. 62-67.

4. Ляшок О. М. Роль медичної сестри в наданні паліативної та хоспісної допомоги / О. М. Ляшок // Медсестринство. - 2015. - № 3. - С. 24-26.

5. Соціально-медичні аспекти розвитку паліативної та хоспісної допомоги в Україні в умовах реформування системи охорони здоров'я / Н. Г. Гойда, Ю. І. Губський, А. В. Царенко // Реабілітація та паліативна медицина. 2015. - № 2. - C. 23-30.

Отримано 05.04.18 